\title{
NAFKAH SAUDARA SEDARAH SESISI (HAWASHI) DALAM UNDANG-UNDANG ISLAM DI MALAYSIA
}

\section{(Maintenance for Blood Relatives (Collaterals) under Islamic Law in Malaysia)}

Badruddin Hj Ibrahim

badruddin@iium.edu.my

Azizah Mohd*

azizahmohd@iium.edu.my

Siti Zainab Abd Rashid

szainab@iium.edu.my

Kulliyah Undang-undang Ahmad Ibrahim, Universiti Islam Antarabangsa Malaysia.

Terbit dalam talian (published online): 2 Julai 2020

Sila rujuk: Hj Ibrahim. B., Mohd, A. dan Abd Rashid, S.Z. (2020). Nafkah Saudara Sedarah Sesisi dalam Undang-undang Islam di Malaysia. Kanun: Jurnal Undang-undang Malaysia, 32(2), 320-340.

\begin{abstract}
Abstrak
Dalam Islam, saudara sedarah sesisi (hawashi) merupakan satu lagi kategori orang-orang yang berhak menerima nafkah daripada saudaramara mereka terutama ketika keadaan memerlukan atau ketika mereka tidak berkemampuan menanggung nafkah diri mereka sendiri sedangkan dalam masa yang sama mempunyai saudara-mara lain yang berkemampuan dan kaya raya. Kajian ini membicarakan tentang "nafkah" kepada saudara sesisi (hawashi) sebagai satu instrumen untuk memastikan perlindungan berterusan kepada saudara-mara di dalam undang-undang Islam. Perbincangan merangkumi pandangan fuqaha tentang nafkah hawashi dalam Islam serta asas tanggungjawab untuk menanggung saudara-mara termasuklah prinsip-prinsip dalam al-Quran
\end{abstract}


dan sunah Rasulullah SAW, dan perbincangan ulama kontemporari terhadap sejauh mana tanggungjawab seseorang untuk menanggung saudara-mara. Seterusnya, kajian ini juga akan meneliti pemakaian undang-undang Islam di Malaysia yang berkaitan dengan tanggungjawab menanggung nafkah saudara-mara. Bagi tujuan perbandingan, perbincangan juga akan merangkumi Peruntukan undang-undang tentang nafkah saudara mara di beberapa buah negara-negara Islam. Kajian ini secara umumnya menggunakan metode kajian perpustakaan dan menganalisis kitab-kitab fiqah dan peruntukan undang-undang tentang nafkah hawashi. Hasil kajian ini dirasakan amat penting bagi tujuan penambahbaikan peruntukan undang-undang Islam tentang nafkah yang sedia ada di Malaysia.

Kata kunci: Nafkah, undang-undang Islam, nafkah adik-beradik, saudara sedarah sesisi (hawashi), undang-undang syariah Malaysia, negara-negara Islam

\begin{abstract}
Under Islamic law, blood relatives from among hawashi (collateral kin) fall into the category of those who deserve nafaqah (maintenance), especially whenever they are in need or when they are incapable of maintaining themselves, while at the same time having relatives who are capable and well off. This research discusses maintenance for collateral relatives as an instrument to ensure continuous protection of relatives under Islamic law. The discussion includes the views of the fuqaha on maintenance to hawashi in Islam. It also reviews the basis for the responsibility to maintain relatives including relevant principles in the Quran and the Sunnah of the Prophet SAW, the discussion and views of contemporary fuqaha (Islamic jurists) on the extent of a person's responsibility to maintain relatives. Further, this research also analyses the application of Islamic law in Malaysia in relation to one's responsibility to maintain relatives. For the purpose of comparison, discussion will also include provisions of the law on maintenance for relatives in several Muslim countries. The research was conducted through library research and analysing the treatises of Muslim jurists, as well as the provisions of Islamic law on maintenance for collateral relatives. The findings of this research are deemed significant to improve the existing provisions on Islamic law relating to maintenance in Malaysia.
\end{abstract}

Keywords: Nafaqah, Islamic law, sibling maintenance, hawashi, Malaysian sharia law, Muslim countries 


\section{PENDAHULUAN}

Kewajipan untuk menanggung nafkah saudara sedarah sesisi kurang diberikan penekanan khususnya di Malaysia pada hari ini. Hal ini menjadi senario biasa di Malaysia sebagai contoh dalam kes nafkah terhadap kanak-kanak, apabila kedua-dua ibu bapa telah meninggal atau tidak berkemampuan, tanggungjawab terhadap nafkah anak-anak akan beralih kepada pemerintah. Sekalipun undang-undang memperuntukkan tanggungjawab seseorang untuk menanggung nafkah saudara-mara, usaha ini tidak dipertingkatkan atau digunakan bagi tujuan membantu dan menolong saudara-mara yang memerlukan. Penyelidikan dalam bidang ini adalah sangat penting kerana maklumatnya boleh membuka mata masyarakat berkenaan nafkah terhadap adik-beradik, saudara-mara dan waris terdekat seseorang individu. Selain itu, kajian seumpama ini memberikan justifikasi bahawa nafkah bukan semata-mata hak bagi saudara-mara bahkan juga memberikan perlindungan berterusan untuk memenuhi keperluan harian terutamanya apabila saudara-mara tidak berkemampuan menanggung diri sendiri.

\section{MAKNA SAUDARA-MARA $(Q A R A B A H)$ DAN HAWASHI}

Saudara-mara (qarabah) dalam bahasa Arab bermakna tali persaudaraan atau mereka yang mempunyai hubungan persaudaraan melalui pertalian darah. ${ }^{1}$ Hawashi ialah sebahagian daripada qarabah yang terdiri daripada saudara-mara yang haram dikahwini (mahram) seperti saudara lelaki seibu sebapa dan anak-anak mereka, saudara perempuan dan anak-anak mereka, bapa saudara dan ibu saudara sebelah bapa, bapa saudara dan ibu saudara sebelah ibu; serta saudara-mara yang tidak haram dikahwini (bukan mahram) seperti anak-anak bapa saudara dan anak-anak emak saudara seibu sebapa, sebelah bapa dan sebelah ibu. ${ }^{2}$

1. Lihat al-Ba'albaki. (1994.) R. Al-Mawrid, Modern Arabic English Dictionary (Edisi Keenam). Dar al-'Ilmi li al-Malayin.

2 Badai' al-Sanai', jil. 4, 30. Lihat juga Muhammad 'Uqlah, Nizam al-Usrah fi alIslam, Edisi Keempat, Maktabah al-Risalah al-Hadithin; Amman, 2010/1431, jil. 3, pp. 489-490. 


\section{PANDANGAN FUQAHA TENTANG NAFKAH SAUDARA SESISI (HAWASHI)}

Para fuqaha bersepakat mengatakan bahawa kedua-dua ibu bapa dan anak-anak adalah antara mereka yang berhak mendapat nafkah. ${ }^{3}$ Walau bagaimanapun, mereka berbeza pendapat sama ada saudara sedarah sesisi berhak mendapat nafkah.

Pada pandangan mazhab Maliki dan Shafii, golongan hawashi tidak berhak mendapat nafkah. Dalam mazhab Maliki, nafkah hanyalah wajib kepada ibu bapa dan anak-anak sahaja. ${ }^{4}$ Sementara itu, dalam mazhab Shafii pula, nafkah hanya wajib kepada ibu bapa dan ke atas, termasuk datuk dan seterusnya dan juga anak-anak ke bawah termasuk cucu dan seterusnya. ${ }^{5}$

Menurut mazhab Hanafi, saudara sedarah sesisi yang berada dalam senarai orang-orang yang haram dikahwini juga mempunyai hak terhadap nafkah. Tidak kira sama ada mereka tergolong sebagai ahli waris atau tidak selagi mereka beragama Islam, kerana mereka berstatus mahram dan haram dikahwini. ${ }^{6}$ Mereka termasuklah adik-beradik lelaki dan perempuan ke bawah, bapa dan ibu saudara seibu sebapa, sebelah bapa dan sebelah ibu. ${ }^{7}$ Sebahagian daripada mereka juga ahli waris yang sah. ${ }^{8}$ Mereka juga dianggap sebagai sebahagian daripada yang lain, tanpa mengambil kira bahawa sesetengah daripada mereka tidak mempunyai hak dalam pewarisan. ${ }^{9}$ Walau bagaimanapun, hak pewarisan merupakan suatu keperluan bagi saudara-mara sebelah ibu yang haram dikahwini dan

3 Tabyin al-Haqa-iq, jil. 3, 63; al-Shirazi, Abu Ishaq Ibrahim ibn Ali ibn Yusuf, alMuhadhdhab fi al-Fiqh al-Imam Al-Shafi'e, (Beirut: Dar al-Kutub al-'Ilmiyyah, t.t.), jil. 3, 158; al-Insaf, jil. 9, 392-393, 396.

4 Muhammad ibn Ahmad ibn 'Arafah al-Dusuqi. (n.d.). Hashiah al-Dusuqi 'ala alSharh al-Kabir, vol. 2, 522. Bayrut: Dar al-Fikr.

5 Zakariyya ibn Muhammad ibn Zakariyya al-Ansari, Asna al-Matalib fi Sharh Rawd al-Talib, (n.p.: Da al-Kitab Islami, n.d.), vol. 9, 83.

6 Badai' al-Sanai', jil. 4, 36.

7 Al-Kasani, 'Ala-addin Abu Bakr ibn Mas'ud ibn Ahmad al- Kasani al-Mazhab Hanafi, Badai' al-Sanai'fi Tartib al-Sharai', (Beirut: Dar al-Kutub al-'Ilmiyyah, edisi kedua., 1986), jil. 4, 30; Fakhruddin al-Zayla'ie, 'Uthman ibn 'Ali ibn Muhjan al-Bari'ie al-Mazhab Hanafi, Tabyin al-Haqaiq Sharh Kanz al-Daqaiq, (Kaherah: Maktabah alKubra al-Amiriyyah, 1312H), jil. 3, 62.

8 Badai'al-Sanai', jil. 4, 36.

9 Ibid. 
saudara sedarah sesisi kerana merupakan syarat yang perlu ditepati bagi membolehkan mereka saling mewarisi antara satu sama lain. ${ }^{10}$

Mazhab Hanbali berpendapat bahawa hanya saudara sedarah sesisi yang sama agama dan merupakan ahli waris sahaja yang berhak mendapat nafkah; kerana saudara-mara yang berlainan agama tidak boleh mewarisi antara satu sama lain. ${ }^{11}$ Berdasarkan pandangan yang lebih diterima (rajih) dalam mazhab Hanbali, ahli waris yang lebih berhak menerima nafkah ialah ashab al-furud dan ashab al-'asabah. ${ }^{12}$

Mazhab Hanafi dan mazhab Hanbali bersandarkan pada ayat-ayat alQuran, sunah dan rasional. Mereka merujuk ayat dalam Surah al-Baqarah yang bermaksud:

... Dan kewajipan bapa pula ialah memberi makan dan pakaian kepada ibu itu menurut pendapatan yang sepatutnya. Tidaklah diberatkan seseorang melainkan menurut kemampuannya. Janganlah menjadikan seseorang ibu itu menderita kerana anaknya, dan (jangan juga menjadikan) seseorang bapa itu menderita kerana anaknya; dan waris juga menanggung kewajipan Yang tersebut (jika si bapa tiada)... ${ }^{13}$

Mazhab Hanafi berpandangan bahawa perkataan waris dalam ayat di atas ialah sintesis perkataan wa 'ala al-mawlud. Hal ini menunjukkan bahawa waris yang berhak mendapatkan nafkah termasuklah anak kecil atau bayi yang baru lahir. Istilah waris dalam ayat ini tidak menunjukkan konotasi asal (hakiki) waris yang sah sedangkan nafkah akan terhenti apabila pencari nafkah meninggal dunia. Oleh sebab istilah warith tidak dalam pengertian asalnya, kelihatan perkataan ini membayangkan

10 Ibn al-Humam, Kamaluddin Muhammad ibn 'Abdul-Wahid al-Siwasi, Fath al-Qadir, (Beirut: Dar al-Fikr, t.t.), jil. 4, 416; Tabyin al-Haqa-iq, jil. 3, 64. Menurut Mazhab Hanafi, saudara sedarah sesisi dari sebelah ibu yang haram dikahwini (mahram) berhak terhadap nafkah dengan syarat mereka saling mewarisi antara satu sama lain serta menganut agama yang sama. Oleh yang demikian, pencari nafkah tidak boleh dipaksa untuk menyara saudara sedarah sesisi yang bukan beragama Islam, tidak juga bagi orang bukan Islam terhadap saudaranya yang beragama Islam.

11 Ibn Qudamah al-Maqdisi, Abu Muhammad Muwafiquddin Abdullah ibn Ahmad ibn Muhammad al-Mazhab Hanbali, al-Mughni, (Kaherah: Maktabah Kaherah, t.t.), jil. 7, 416; Al-Bahuti, Mansur ibn Yunus ibn Solahuddin ibn Hassan ibn Idris al-Mazhab Hanbali, Kashshaf al-Qana' 'an Matn al-Iqna', (Beirut: Dar al-Kutub al-'Ilmiyyah, t.t.), jil. 5, 481-482.

12 Ibid.

13 Surah al-Baqarah 2:233 
gambaran umum mengenai keperluan status orang-orang yang berpotensi menjadi waris dalam kes nafkah, iaitu ia telah ditentukan sebagai waris yang berada dalam kategori orang-orang yang haram dikahwini. Selain itu, nafkah ini bukanlah untuk nafkah isteri kerana nafkah beliau adalah atas tanggungjawab suaminya; tidak juga atas saudara-mara yang kaya. Tambahan pula, ayat ini tidak bermaksud ditujukan untuk waris yang mempunyai hak dalam pewarisan, tetapi khusus untuk waris yang haram dikahwini. ${ }^{14}$ Mazhab Hanafi juga merujuk riwayat Ibn Mas'ud yang menyatakan bahawa bacaan ayat tersebut adalah "wa.ala al-warith wa fi rahmi al-mahram mithlu zaalik", yang bermaksud ahli waris di sini merujuk kepada mahram atau ahli waris yang haram dikahwini. Walaupun bacaan ini tidak sabit daripada ayat al-Quran oleh sebab tidak bersifat tawatur ${ }^{15}$ tetapi ulama mazhab Hanafi berpendapat bahawa riwayat ini merupakan penjelasan kepada ayat tersebut yang telah didengar daripada Rasulullah SAW. ${ }^{16}$ Walau bagaimanapun, mazhab Hanbali berpegang pada makna zahir nas tersebut yang merujuk kepada ahli waris. ${ }^{17}$

Satu lagi ayat al-Quran yang kelihatan lebih khusus mengenai nafkah untuk saudara sedarah sesisi (hawashi) ialah:

Dan hendaklah kamu beribadat kepada Allah dan janganlah kamu sekutukan Dia dengan sesuatu apa jua; dan hendaklah kamu berbuat baik kepada kedua-dua ibu bapa, dan kaum kerabat ... ${ }^{18}$

Ayat di atas ialah bukti menunjukkan bahawa Allah SWT telah meletakkan hak kaum kerabat dan sanak saudara selepas hak terhadap ibu bapa apabila Dia memerintahkan manusia supaya melakukan kebaikan terhadap mereka sama seperti yang dilakukan terhadap kedua-dua ibu bapa. Perlakuan ini merupakan sebesar-besar perbuatan menyakiti dengan melihat kaum kerabat menahan lapar, dan membiarkan mereka dalam

14 Fath al-Qadir, jil. 4, 417; Ahmad ibn Ali Abu Bakr al-Razi al-Jassas al-Mazhab Hanafi, Ahkam al-Quran, (Beirut: Dar Ihya al-Turath, 1405H), jil. 2, 112; al-Bahr al-Ra-iq, jil. 4, 228.

15 Bacaan yang dinukilkan oleh ramai dan tiada kemungkinan yang mereka akan bersepakat kepada pendustaan

16 Lihat Muhammad Mustafa Shalabi, Ahkam al-Usrah fi al-Islam, Beirut; Dar alNahdah al-'Arabiyyah, 1977, 825.

17 Lihat Ahmad Muhammad Ismail Barraj, al-Dhaman al-Ijtima'I fi al-Fiqh al-Islami, Iskandariyyah; Dar al-Jami'ah al-Jadidah, 2013, 276.

18 Surah An-Nisa' 4:36. 
keadaan tidak berpakaian sedangkan ada ahli keluarga yang berkemampuan untuk menghulurkan bantuan. ${ }^{19}$ Dalam ayat lain seterusnya menyebut:

... jika kamu dapat memegang Kuasa - kamu akan melakukan kerosakan di muka bumi, dan memutuskan hubungan silaturahim dengan kaum kerabat? $?^{20}$

...dan orang-orang yang mempunyai pertalian kerabat, setengahnya lebih berhak (mewarisi) akan setengahnya yang lain - menurut (hukum) Kitab Allah ... ${ }^{21}$

Dalam ayat di atas, Allah SWT memerintahkan manusia supaya memelihara hubungan antara saudara-mara, dan sebarang usaha untuk memutuskan hubungan tersebut dilarang. Perkataan "pertalian kerabat" dalam ayat kedua menunjukkan kaum kerabat dan saudara terdekat, kerana perbezaan antara saudara-mara dekat dan jauh dalam undang-undang Islam adalah melalui pengharaman perkahwinan. Oleh itu, menyediakan bantuan dan nafkah dianggap sebagai suatu cara untuk menyambungkan hubungan dalam kalangan sanak saudara yang haram dikahwini. ${ }^{22}$

Tahap hubungan rapat dalam kalangan saudara-mara sedarah telah ditegaskan (dalam Islam) melalui pengharaman perkahwinan; mereka akan dibebaskan jika mereka hamba dan hukuman potong tangan tidak akan dilaksanakan jika mereka didapati bersalah kerana mencuri; sedangkan mereka yang tidak haram dikahwini tidak menikmati keistimewaan yang sama. Oleh itu, ayat-ayat di atas kelihatan mengenakan tanggungjawab memberi nafkah kepada saudara-mara, dan pengabaian ketika seseorang mempunyai kemampuan untuk memberikan bantuan jelas akan memutuskan hubungan persaudaraan. ${ }^{23}$ Dalam satu hadis sahih, Rasulullah SAW bersabda: ${ }^{24}$

Tariq Al-Muharibi meriwayatkan: "Kami telah datang ke Madinah dan Rasulullah sedang berdiri di atas mimbar memberikan ucapan kepada

19 Rashad Hasan Khalil, Nafaqat al-Aqaribfi al-Fiqh al-Islami, (Kaherah: Dar al-Manar, 1987), 58.

20 Surah Muhammad 47:22

21 Surah Al-Ahzab 33:6

22 Badai'al-Sanai', jil. 4, 31.

23 Ibid.

24 An-Nasa-ie, Abu Abdurrahman Ahmad ibn Shu'aib ibn Ali al-Khurasani, al-Sunan al-Sughra li an-Nasa-ie, (Halab: Maktab al-Matbu'aat al-Islamiyyah, Edisi Kedua, 1986), jil. 5, 61 . 
hadirin dan berkata: Tangan yang memberi lebih mulia. Mulakan dengan orang-orang yang kamu bertanggungjawab; ibumu, ayahmu, saudara perempuanmu, saudara lelakimu, kemudian yang paling hampir denganmu, dan seterusnya. ${ }^{25}$ "

Dalam hadis lain: ${ }^{26}$

Kulayb ibn Manfa'ah meriwayatkan bahawa datuknya telah pergi (bertemu) Rasulullah dan berkata: Ya Rasulullah! Kepada siapa harus aku melakukan kebaikan? Baginda bersabda: ibumu, ayahmu, saudara perempuanmu, saudara lelakimu dan hamba yang kau merdekakan yang juga saudaramu, bagi mereka ada hak yang wajib atasmu yang perlu diberikan kepada mereka, serta ikatan persaudaraan yang perlu disambungkan.

Hadis di atas dengan jelas menyenaraikan saudara-mara yang berhak mendapat nafkah, perhatian dan kasih sayang. Hadis ini menunjukkan bahawa seseorang Muslim itu bertanggungjawab menyediakan nafkah kepada saudaranya. Berdasarkan perbincangan di atas, pada pandangan mazhab Hanafi dan Hanbali, saudara sesisi berhak mendapat nafkah berdasarkan dalil daripada al-Quran dan Sunah. Tuntutan ini adalah untuk memelihara hubungan silaturrahim dengan kaum kerabat yang rapat. Pada masa yang sama, berbuat kebaikan kepada saudara-mara terdekat yang haram dikahwini (mahram) selepas ibu bapa dan anak-anak merupakan tanggungjawab yang wajib dipenuhi. Pendapat ini juga telah disebut dan dibincangkan dengan jelas oleh para fuqaha kontemporari, contohnya Zaki al-Din Sha'aban dalam bukunya al-Ahkam al-Shar'iyyah fi al-Ahwal al-Shakhsiyyah. ${ }^{27}$

Pendapat mazhab Fiqah di atas tentang nafkah hawashi juga diketengahkan dengan agak terperinci oleh Muhammad Mustafa Shalabi, Muhammad 'Aqalah dan Muhammad Ismail al-Baraj dalam buku mereka. Dalam mentarjihkan pandangan tersebut, mereka telah memilih pandangan

25 Nasiruddin al-Khattab, English Translation of Sunan An-Nasa-ie, (Riyadh: Darussalam, 2007), jil. 3, 363.

26 Abu Dawud, Sulayman ibn al-Ash'ath ibn Ishaq ibn Bashir ibn Shaddad ibn 'Amru al-Azdi al-Sijistani, Sunan Abi Dawud (jil. 4, p. 336). (n.d.). Beirut: al-Maktabah al'Asriyyah. .

27 See Zaki al-Din Sha'aban. (1993). Al-Ahkam al-Shar'iyyah li al-Ahwal al-Shakhsiyyah (6 $6^{\text {th }}$ Edition, pp. 675-679). Banghazi; Jami'ah Qaryunis. 
mazhab Hanbali atas alasan pandangan tersebut adalah lebih luas dan lebih dekat dengan nas-nas syarak. Pandangan mazhab Hanbali adalah lebih selaras dengan kaedah fiqah yang bermaksud "yang menanggung atau bertanggungjawab akan juga mendapat manfaat (al-ghurmu bi al-Ghunmi)" dan juga maqasid al-syariah dalam keadilan dan memelihara keluarga. ${ }^{28}$

\section{SYARAT-SYARAT NAFKAH}

Para fuqaha juga telah membincangkan berkenaan tanggungjawab menanggung saudara-mara yang timbul apabila beberapa syarat telah dipenuhi, syarat-syarat tersebut termasuklah:

(1) Papa, miskin dan tidak berkeupayaan untuk memperoleh pendapatan.

Mazhab Hanafi berpandangan bahawa saudara-mara berhak mendapat nafkah jika mereka berada dalam keadaan papa dan miskin serta tidak berkeupayaan untuk memperoleh pendapatan. ${ }^{29}$

Mazhab Hanbali mempunyai pandangan yang hampir serupa dengan mazhab Hanafi. Mereka berpandangan bahawa saudara sedarah sesisi (hawashi) yang berhak mendapat nafkah mestilah daripada kalangan orang-orang yang tidak berkeupayaan mencari pendapatan, kerana adalah menjadi tanggungjawab mereka untuk bekerja bagi menampung kehidupan mereka sendiri. ${ }^{30}$

(2) Pemberi nafkah ada kemampuan.

Mazhab Hanafi dan mazhab Hanbali sepakat bahawa pemberi nafkah mestilah seorang yang berharta atau mempunyai wang dan dana yang mencukupi untuk menampung keperluan asas beliau. Berkenaan nafkah terhadap saudara sedarah sesisi, mazhab Hanafi berbeza pendapat mengenai ukuran nilaian dalam menentukan siapakah

28 Lihat Muhammad Mustafa Shalabi, Ahkam al-Usrah fi al-Islam (p. 826). (1977). Beirut; Dar al-Nahdah al-'Arabiyyah. ; Ahmad Muhammad Ismail Barraj. (2013). al-Dhaman al-Ijtima'Ifi al-Figh al-Islami (p. 277). Iskandariyyah; Dar al-Jami’ah alJadidah.; Muhammad 'Aqalah. (2010). Nizam al-Usrah fi al-Islam (Juzuk 3, Cetakan Keempat, p. 505). Amman: Maktabah al-Risalah al-Hadithah.

29 Badai'al-Sanai', jil. 4, 34.

30 Kashshaf al-Qana', jil. 5, 481. 
kalangan saudara-mara yang bertanggungjawab menyediakan nafkah. ${ }^{31}$ Menurut Abu Yusuf, kemampuan (untuk menyediakan nafkah) boleh ditentukan berdasarkan jumlah yang mewajarkannya membayar zakat (nisab al-zakat). Oleh itu, tanggungjawab untuk menyediakan nafkah akan diberikan kepada sesiapa sahaja yang memiliki jumlah tersebut dengan syarat beliau juga telah memenuhi syarat-syarat lain bagi nafkah.

Mereka selanjutnya menegaskan bahawa nafkah untuk dhawil-Arham hanyalah berbentuk hadiah semata-mata yang tidak memerlukan sebarang bayaran ganti rugi; dan hadiah dalam bentuk begini adalah wajib diberikan oleh orang-orang yang berharta, sama seperti sedekah. Selain itu, ukuran bagi seseorang untuk dianggap kaya menurut undang-undang Islam adalah apabila jumlah harta telah mencapai jumlah nisab untuk membayar zakat (al-nisab zakat).

Menurut Muhammad al-Shaybani, kemampuan ditentukan mengikut jumlah berlebihan daripada perbelanjaan bulanan orang yang bertanggungjawab menyediakan nafkah. Pandangan ini mengambil kira bahawa seseorang dianggap berharta dan kaya jika beliau mempunyai sebarang jumlah berlebihan daripada perbelanjaannya dalam masa satu bulan. Tambahan pula, masih ada masa yang mencukupi untuk mencari pendapatan sepanjang bulan. Oleh itu, menjadi kemestian baginya untuk membelanjakan jumlah yang berlebihan kepada saudara-maranya yang terdekat. Pandangan ini lebih diterima di sisi mazhab Hanafi, kerana jumlah yang mewajarkan pemiliknya untuk membayar zakat berada dalam kategori hak Allah (huququllah); sementara nafkah ialah hak hamba ( $h u q u q$ al-'Abd), dan tidak boleh diukur dengan jumlah yang dikira sebagai hak Allah. Walau bagaimanapun, jumlah tersebut, yang menyebabkan pemiliknya membayar zakat boleh diambil kira sebagai standard keupayaan untuk membayar nafkah, kerana orang yang ditanggung (berhak mendapat nafkah) yang diambil kira mengikut keperluan. Oleh itu, bagi penyumbang nafkah, jumlah yang berlebihan itu dianggap sebagai ukuran kemampuan untuk menyediakan nafkah kerana pemberiannya hanya boleh dilakukan apabila terdapat baki daripada keperluan asas pencari nafkah. ${ }^{32}$

Bagi mazhab Hanbali, pemberi nafkah dikehendaki mempunyai jumlah yang berlebihan daripada perbelanjaan untuk dirinya, isterinya,

31 Badai'al-Sanai', jil. 4, 35.

32 Badai'al-Sanai', jil. 4, 35. 
dan hamba-hambanya, pada waktu siang dan malam; sebelum nafkah dipertanggungjawabkan kepada saudara-maranya, sama ada usul, furu', atau waris. Nafkah tersebut, sama ada daripada harta atau pendapatan beliau. Oleh itu, sekiranya tidak ada sebarang jumlah berbaki daripada perbelanjaan beliau, maka tidak akan ada nafkah untuk saudara-mara yang berhak mendapatkan nafkah tersebut. Hal ini disebabkan nafkah untuk saudara-mara terdekat hanyalah sebagai penenang hati dan simpati dan bukanlah suatu kewajipan seperti kewajipan membayar zakat. ${ }^{33}$

(3) Menganut agama yang sama

Mazhab Hanafi dan Mazhab Hanbali juga berpendapat bahawa salah satu syarat nafkah terhadap saudara sedarah sesisi (hawashi) ialah pemberi nafkah dan orang yang ditanggung mestilah menganut agama yang sama. Hal ini merupakan satu keperluan bagi saudara sedarah sesisi bagi melayakkan mereka dalam pewarisan. ${ }^{34}$

(4) Darah orang yang ditanggung adalah terpelihara ( $m$ a sum al-dam)

Menurut mazhab Hanafi darah orang yang ditanggung adalah terpelihara. Mereka berpendapat bahawa orang yang ditanggung mestilah bukanlah harbi, musta'min, atau murtad, kerana golongan ini tidak boleh mewarisi antara satu sama lain. ${ }^{35}$

(5) Orang yang merdeka, bukan hamba

Para fuqaha bersepakat bahawa pemberi nafkah dan orang yang ditanggung mestilah seorang yang merdeka dan bukannya hamba. Ijmak para fuqaha mengatakan bahawa nafkah bagi hamba adalah atas tuannya. ${ }^{36}$

33 Kashshaf al-Qana', jil. 5, 482.

34 Tabyin al-Haqaiq, jil. 3, 64; al-Mughni, jil. 7, 584.

35 Badai'al-Sanai', jil. 4, 37; Asna al-Matalib, jil. 3, 443.

36 Badai'al-Sanai', jil. 4, 39; Hashiah al-Dusuqi, jil. 2, 522; Asna al-Matalib, jil. 3, 443; Kashshaf al-Qana', jil. 5, 482. 
(6) Nafkah bagi saudara sedarah sesisi melalui perintah Hakim/Kadi.

Mazhab Hanafi berpandangan bahawa kewajipan menyediakan nafkah untuk saudara sedarah sesisi mestilah diberikan kepada pemberi nafkah melalui perintah kadi. Ini kerana nafkah ini hanyalah berbentuk hadiah yang tiada bayaran ganti rugi yang akan dibuat. Oleh itu, kewajipan tersebut bergantung atas perintah daripada kadi. ${ }^{37}$ Fuqaha juga berbeza pendapat tentang orang yang bertanggungjawab menyediakan nafkah apabila terdapat beberapa orang pemberi nafkah. Menurut mazhab Hanafi, apabila didapati ada beberapa orang pemberi nafkah yang terdiri dalam kalangan saudara sedarah sesisi, pertama yang perlu diambil kira ialah "saudara yang haram dikahwini (mahram) daripada sebelah ibu". Tanpa hubungan ini, kewajipan menyediakan nafkah tidak akan dipertanggungjawabkan terhadap individu tersebut. Sebagai contoh, dalam kes apabila seorang saudara memerlukan mempunyai bapa saudara sebelah ibu dan anak lelaki bapa saudara sebelah bapa. Dalam kes ini, nafkah akan dipertanggungjawabkan terhadap bapa saudara sebelah ibu kerana perbezaan tahap hubungan persaudaraan (mahram daripada sebelah ibu). ${ }^{38}$

Di samping itu, pemberi nafkah juga mesti mempunyai kelayakan dalam pewarisan. Sebagai contoh, jika saudara memerlukan mempunyai ibu saudara sebelah bapa, bapa saudara atau ibu saudara sebelah ibu, kesemua mereka akan berkongsi tanggungjawab terhadap nafkah kerana mereka mempunyai kelayakan dalam pewarisan. Ibu saudara sebelah bapa akan menyediakan dua pertiga, dan selebihnya kepada bapa saudara atau ibu saudara sebelah ibu.

Apabila didapati beberapa orang pemberi nafkah yang memenuhi kedua-dua keperluan, saudara sedarah sesisi yang juga waris hakiki akan mengatasi saudara-mara yang lain. Sebagai contoh, seorang saudara yang memerlukan mempunyai bapa saudara dan ibu saudara sebelah bapa, dan ibu saudara sebelah ibu. Nafkah akan dipertanggungjawabkan kepada bapa saudara sebelah bapa sekalipun mereka berkongsi darjah hubungan yang sama (saudara sedarah sesisi) akan tetapi disebabkan bapa saudara sebelah bapa memenuhi kedua-dua keperluan dan juga waris hakiki, tanggungjawab terhadap nafkah akan diberikan kepadanya. ${ }^{39}$

37 Badai'al-Sanai', jil. 4, 37.

38 Badai'al-Sanai', jil. 4, 33.

39 Ibid. 
Tambahan pula, bagi beberapa orang pemberi nafkah yang memenuhi semua keperluan, mereka akan berkongsi beban tanggungjawab ini dan masing-masing akan menyumbangkan nafkah mengikut bahagian mereka dalam pewarisan. Sebagai contoh, dalam kes apabila seorang saudara yang memerlukan mempunyai saudara perempuan seibu sebapa, saudara perempuan sebapa dan bapa saudara sebelah bapa; saudara perempuan seibu sebapa akan menyediakan sebanyak satu perdua, saudara perempuan sebapa sebanyak satu perenam, dan selebihnya adalah daripada bapa saudara (satu pertiga). Pembahagian ini berdasarkan kepada bahagian mereka dalam pewarisan. ${ }^{40}$

Dalam kes apabila pemberi nafkah yang memenuhi kedua-dua keperluan tetapi tidak dapat berbuat demikian kerana papa, boleh digambarkan dalam dua keadaan:

(7) Apabila pemberi nafkah berhak mendapat bahagian penuh dalam pewarisan. Dalam keadaan ini, pemberi nafkah yang papa kedana ini akan dianggap sebagai orang yang telah meninggal dan nafkah akan disediakan oleh pemberi nafkah yang lain mengikut bahagian mereka dalam pewarisan.

Sebagai contoh, saudara yang memerlukan mempunyai seorang anak lelaki yang miskin dan tidak berkeupayaan untuk mencari pendapatan, saudara perempuan seibu sebapa, dan bapa saudara sebelah bapa. Anak lelaki, yang berhak mendapat bahagian penuh dalam pewarisan, akan dianggap sebagai orang yang telah meninggal. Oleh itu, saudara perempuan seibu sebapa dan bapa saudara sebelah bapa akan menyediakan nafkah. Mereka akan berkongsi tanggungjawab ini: saudara perempuan seibu sebapa akan menyediakan $1 / 2$, dan selebihnya daripada bapa saudara sebelah bapa (1/2). Pembahagian tanggungan nafkah selaras dengan bahagian mereka dalam pewarisan. ${ }^{41}$

(8) Apabila pemberi nafkah tidak berhak mendapat bahagian penuh dalam pewarisan. Dalam hal ini, beliau tidak akan dianggap sebagai orang yang telah meninggal, bahkan akan berkongsi tanggungjawab menyediakan nafkah bersama-sama pencari nafkah atau waris yang lain.

40 Ibid., jil. 4, 34.

41 Ibid. 
Sebagai contoh, saudara yang memerlukan mempunyai anak perempuan yang miskin, saudara lelaki seibu sebapa, saudara lelaki sebapa, dan saudara lelaki seibu. Dalam keadaan ini, nafkah akan dipertanggungjawabkan atas saudara lelaki seibu sebapa sahaja, kerana anak perempuan tidak berhak mendapat bahagian penuh dalam pewarisan ayahnya (hanya $1 / 2$ sahaja mengikut bahagian beliau dalam pewarisan). Anak perempuan tidak akan dianggap sebagai orang yang telah meninggal dan beliau juga tidak akan bertanggungjawab terhadap nafkah kerana keadaannya yang miskin itu. Oleh itu, nafkah akan dipertanggungjawabkan atas saudara lelaki seibu sebapa sahaja kerana saudara lelaki sebapa tidak boleh mewarisi (mahjub/terhalang) kerana kewujudan saudara lelaki seibu sebapa; tidak juga saudara lelaki seibu (mahjub juga) kerana kewujudan anak perempuan. ${ }^{42}$

Menurut mazhab Hanbali, dalam kes apabila terdapat beberapa orang pemberi nafkah yang terdiri dalam kalangan saudara sedarah sesisi, tanggungjawab menyediakan nafkah akan dikongsi oleh individu yang berada dalam senarai pewarisan, berdasarkan bahagian masing-masing. Sebagai contoh, dalam kes saudara yang memerlukan mempunyai saudara perempuan seibu sebapa dan bapa saudara seibu sebapa, nafkah akan dibahagikan kepada dua bahagian, kerana ini merupakan bahagian mereka dalam pewarisan. Dalam contoh lain, saudara yang memerlukan mempunyai saudara lelaki seibu sebapa, saudara lelaki sebapa dan saudara lelaki seibu. Nafkah akan dipertanggungjawabkan kepada saudara lelaki seibu sebapa dan saudara lelaki seibu. Saudara lelaki seibu akan menyumbang sebanyak 1/6 daripada nafkah dan selebihnya atas tanggungan saudara lelaki seibu sebapa. ${ }^{43}$

Dalam kes apabila pemberi nafkah seorang yang papa kedana, dan ada pemberi nafkah lain tetapi terhalang (mahjub) dalam pewarisan, tanggungjawab terhadap nafkah tidak akan dipindahkan kepada orang yang terhalang tersebut. Sebagai contoh, saudara yang memerlukan mempunyai saudara lelaki seibu sebapa yang miskin dan saudara lelaki sebapa yang berada. Tanggungjawab terhadap nafkah tidak akan dipindahkan kepada saudara lelaki sebapa kerana keadaan saudara lelaki seibu sebapa yang tidak memenuhi syarat terhadap nafkah disebabkan keadaannya yang

42 Ibid.

43 Kashshaf al-Qana', jil. 5, 482. 
miskin itu. ${ }^{44}$ Begitu juga, beberapa orang pemberi nafkah yang tidak terhalang dalam pewarisan akan berkongsi tanggungjawab terhadap nafkah berdasarkan bahagian mereka dalam pewarisan. Sebagai contoh, saudara yang memerlukan mempunyai saudara lelaki seibu sebapa yang papa dan saudara lelaki seibu yang berharta. Nafkah akan menjadi tanggungjawab saudara lelaki seibu kerana beliau boleh mewarisi bersama-sama dengan saudara lelaki seibu sebapa. ${ }^{45}$

\section{PERUNTUKAN UNDANG-UNDANG ISLAM DI MALAYSIA}

Undang-undang yang mentadbir umat Islam berkaitan nafkah di Malaysia ialah Akta Undang-undang (Wilayah-Wilayah Persekutuan) 1984 (AUKI) dan Enakmen Negeri-Negeri. Pada dasarnya, AUKI dan Enakmen NegeriNegeri mengiktiraf hak isteri, anak-anak dan saudara-mara terhadap nafkah. Peruntukan tentang nafkah isteri dan anak-anak agak lengkap dan terperinci. ${ }^{46}$ Walau bagaimanapun, peruntukan berkaitan nafkah terhadap saudara-mara selain isteri dan anak-anak, agak umum dan hanya ada satu peruntukan sahaja yang menyebut:

"Mahkamah boleh memerintahkan mana-mana orang yang bertanggungan tentang hal itu mengikut Hukum Syarak, supaya membayar nafkah kepada seseorang lain jika dia tak upaya, sepenuhnya atau sebahagiannya, daripada mencari kehidupan oleh sebab kerosakan otak atau jasmani atau tidak sihat dan Mahkamah berpuas hati bahawa memandang kepada kemampuan orang yang pertama tersebut itu adalah munasabah memerintahkan sedemikian." ${ }^{, 77}$

Menurut The Annotated Statutes of Malaysia, perkataan "seseorang lain" dalam peruntukan di atas merujuk ibu bapa dan terhadap serta semua kaum kerabat terdekat yang haram dikahwini. ${ }^{48}$ Tidak ada tafsiran atau penerangan lain yang lebih khusus mengenai peruntukan di atas

44 Saudara lelaki sebapa juga tidak dipertanggungjawabkan terhadap nafkah kerana beliau terhalang (dalam pewarisan) kerana kewujudan saudara lelaki seibu sebapa.

45 Ibid. jil. 5, 483.

46 Lihat Akta Undang-Undang Keluarga Islam (Wilayah Persekutuan) 1984, seksyen 59-80.

47 Akta Undang-Undang Keluarga Islam (Wilayah Persekutuan) 1984, seksyen 60.

48 See The Annotated Statutes of Malaysia. (2010). Islamic Family Law (Federal Territories) Act 1984, sect. 60, p. 501. 
terhadap saudara-mara atau ruang lingkup bagi saudara-mara. Tafsiran yang lanjut mengenai peruntukan di atas, boleh dilihat melalui aplikasi kes di mahkamah syariah yang mengguna pakai peruntukan pada isu yang berkaitan dengan hak ibu bapa terhadap nafkah. Sebagai contoh, dalam kes Kassim bin Othman \& Fatimah binti Salleh lwn Raja Suzana binti Raja Kasim \& Zul Azli bin Hashim ${ }^{49}$ pihak yang menuntut merupakan ibu bapa kepada defendan 1 dan ibu bapa mentua defendan 2 telah menuntut nafkah sara hidup mereka. Mahkamah antara lain telah merujuk Seksyen 61, Enakmen Undang-undang Keluarga Islam (Negeri Sembilan) 2003 yang lebih kurang sama dengan peruntukan seksyen 60 AUKI 1984 seperti yang dinyatakan di atas. ${ }^{50}$ Mahkamah telah memutuskan bahawa pihak defendan bertanggungjawab untuk memberikan nafkah kepada ibu bapa mereka antara lain berdasarkan peruntukan tersebut. Kes ini menunjukkan bahawa peruntukan seksyen 60 AUKI terpakai kepada nafkah ibu bapa walaupun hal ini tidak dinyatakan dengan jelas dalam peruntukan tersebut. Akan tetapi pemakaiannya berdasarkan pemakaian dan aplikasi yang lebih umum kerana terma yang digunakan ialah "mana-mana orang yang bertanggungan tentang hal itu mengikut Hukum Syarak". Oleh sebab itu, dapatlah disimpulkan bahawa, peruntukan ini boleh juga terpakai kepada kaum kerabat daripada saudara sesisi (hawashi) selagi tanggungjawab untuk memberi nafkah adalah bertepatan dan selari dengan hukum syarak.

Oleh itu, berdasarkan peruntukan di atas, seorang saudara sedarah sesisi yang tidak berkeupayaan menanggung dirinya sendiri boleh memohon mendapatkan perintah Mahkamah untuk memerintahkan saudaranya supaya menyediakan nafkah kepadanya. Tambahan pula, sekalipun pada hakikatnya bahawa ramai umat Islam di Malaysia berpegang kepada mazhab Syafii, hakim mahkamah syariah boleh juga merujuk pandangan mazhab lain seperti mazhab Hanafi dan mazhab Hanbali kerana undangundang Islam seperti yang ditakrifkan di bawah AUKI hendaklah merangkumi empat mazhab Ahli Sunah Waljamaah yang lain. ${ }^{51}$ Walau bagaimanapun, dalam kes yang melibatkan saudara sedarah sesisi, setakat

49 Sebagai contoh, lihat kes Kassim bin Othman \& Fatimah binti Salleh lwn Raja Suzana binti Raja Kasim \& Zul Azli bin Hashim, (2010) $30 \mathrm{JH}(2)$, 299. Lihat juga Badruddin Hj Ibrahim \& Azizah Mohd. (2007). Parental Rights to Maintenance under Islamic Law. ShLR, (4) 2007.

50 See Kassim bin Othman \& Fatimah binti Salleh lwn Raja Suzana binti Raja Kasim \& Zul Azli bin Hashim, p. 310-311.

51 Lihat Akta Undang-Undang Keluarga Islam (Wilayah Persekutuan) 1984, seksyen 2. 
ini tiada kes dilaporkan berkenaan perintah mahkamah untuk menyediakan nafkah kepada saudara sedarah sesisi.

\section{PERUNTUKAN DI BEBERAPA NEGARA ISLAM}

Undang-undang Islam berkenaan kewajipan menanggung saudara-mara telah diterima pakai dan digunakan di beberapa negara Islam. Undangundang Keluarga Jordan (2010) $)^{52}$ menerima pakai pandangan mazhab Hanbali berkenaan nafkah terhadap saudara-mara. Seksyen 198 dengan jelas memperuntukkan bahawa peruntukan nafkah kepada anak bawah umur yang miskin dan orang dewasa yang miskin yang tidak berkemampuan untuk bekerja untuk menyara kehidupan disebabkan kekurangan fizikal atau mental adalah wajib terhadap saudara-mara yang berhak mewarisi daripada mereka berdasarkan bahagian mereka dalam pewarisan. Dalam kes jika saudara-mara yang bertanggungjawab terhadap nafkah adalah miskin, nafkah akan dipertanggungjawabkan kepada waris yang terdekat; namun mereka boleh menuntut semula bayaran balik daripada saudaramara yang bertanggungjawab terhadap nafkah jika mereka berkemampuan dan berada.

Undang-undang Keluarga Iraq $1959^{53}$ memperuntukkan bahawa jika bapa tidak berkeupayaan untuk menyediakan nafkah untuk anaknya, ia akan dipertanggungjawabkan kepada sesiapa yang bertanggungjawab terhadap nafkah anak tersebut sekiranya anak itu tidak mempunyai bapa. Nafkah akan menjadi hutang yang terhutang kepada orang yang menyediakannya yang perlu diselesaikan oleh bapa jika kedudukan kewangan beliau semakin pulih. ${ }^{54}$ Nafkah bagi setiap orang miskin yang tidak berkemampuan mencari pendapatan hendaklah dipertanggungjawabkan kepada saudaramaranya yang kaya yang akan mewarisi daripada beliau, berdasarkan peratusan yang layak bagi mereka dalam pewarisan. Sementara itu, nafkah untuk saudara-mara akan diputuskan bermula dari tarikh litigasi. ${ }^{55}$

Undang-undang Keluarga Qatar 2006 memperuntukkan bahawa nafkah untuk saudara-mara adalah wajib kepada pemberi nafkah sebagai satu cara untuk memberikan sokongan bertujuan untuk melakukan perbuatan yang

\footnotetext{
52 Akta No. 26

53 No. 188 tahun 1959.

54 Undang-Undang Keluarga Iraq 1959, artikel 60.

55 Undang-Undang Keluarga Iraq, artikel $62-63$.
} 
baik. ${ }^{56}$ Ibu yang mempunyai pendapatan hendaklah bertanggungjawab menyediakan nafkah kepada anaknya semasa ketiadaan bapa atau bapa kepada bapa, atau tidak mempunyai harta, atau miskin. ${ }^{57}$ Undang-undang seterusnya memperuntukkan nafkah terhadap saudara-mara yang secara am menyatakan bahawa, dengan mengambil kira artikel 78 daripada undang-undang ini, nafkah hendaklah dipertanggungjawabkan kepada waris yang mempunyai hak dalam pewarisan dan mempunyai pendapatan untuk menyediakan nafkah mengikut bahagian masing-masing. Jika waris tidak berkemampuan disebabkan keadaannya yang miskin, waris yang paling hampir akan mengambil alih tanggungjawab. Orang yang berkewajipan terhadap nafkah dan tidak mampu untuk menyara beberapa orang saudara yang berhak mendapat nafkah hendaklah mengutamakan nafkah untuk isterinya, diikuti oleh anak-anaknya, kemudian ibu bapanya, kemudian saudara-mara terdekat. Saudara-mara berhak mendapat nafkah bermula dari tarikh permohonan difailkan. ${ }^{58}$

Undang-undang Keluarga Emiriyah Arab Bersatu (UAE), Qanun Ittihadi 2005 Dalam Perkara Ahwal al-Shakhsiyyah memperuntukkan kewajipan menanggung nafkah saudara sesisi berdasarkan tertib dan bahagian ahli waris dalam pewarisan, iaitu wajib atas ahli waris yang kaya dan berada untuk menanggung nafkah saudara-mara berdasarkan tertib bahagian mereka dalam pewarisan harta pusaka. ${ }^{59}$

Perbincangan tentang peruntukan nafkah kepada saudara-mara dan kaum kerabat di beberapa buah negara Islam di atas menunjukkan bahawa saudara-mara dan kaum kerabat termasuklah saudara-mara sesisi (hawashi) merupakan antara saudara-mara yang wajib diberikan perhatian untuk memberikan nafkah terutama apabila mereka tidak mempunyai harta dan tidak berupaya menanggung nafkah diri mereka. Peruntukan ini juga selari dengan hukum syarak dan juga peruntukan undang-undang berkaitan orang Islam di Malaysia. Walau bagaimanapun secara khususnya, pendapat mazhab kontemporari serta peruntukan undang-undang di negara Islam lebih cenderung kepada pendapat mazhab Hanbali, iaitu nafkah hawashi diwajibkan hanya kepada golongan hawashi yang merupakan ahli waris. Hal ini selaras dengan kaedah fiqah dan juga maqasid al-Syariah dalam

56 Undang-Undang Keluarga Qatar 2006, artikel 74.

57 Undang-Undang Keluarga Qatar 2006, artikel 78.

58 Undang-Undang Keluarga Qatar 2006, artikel 82 to 84.

59 Qanun Ittihadi (UAE) 2005 Dalam Perkara Ahwal al-Shakhsiyyah no. 28, section 84. 
memberi keadilan kepada ahli keluarga dan ia menjadi salah satu instrumen jaminan kehidupan kepada ahli keluarga.

\section{KESIMPULAN}

Islam menjamin perlindungan hak dan memastikan pelaksanaannya dengan mengenakan tanggungjawab tersebut terhadap golongan tertentu yang tersenarai berkewajipan untuk menunaikan tanggungjawab tertentu. Sebagai sebahagian daripada ahli dalam satu keluarga, maka menjadi tanggungjawab saudara-mara untuk sentiasa peka dengan tugas, khususnya tanggungjawab menyediakan nafkah terhadap saudara-mara yang lain. Apatah lagi jika terdapat permohonan daripada kalangan saudara-mara untuk ditanggung. Nafkah terhadap saudara-mara akan menjamin dan membolehkan mereka untuk meneruskan kehidupan serta menghilangkan kesusahan yang mungkin mereka hadapi disebabkan kemiskinan. Nafkah dapat memastikan saudara-mara tidak hidup dalam kesusahan dan kemiskinan dan hidup dalam kebahagiaan dan keharmonian. Bagi merealisasikan tujuan ini, kebanyakan negara Islam termasuk Malaysia telah menerima dan mengguna pakai peruntukan undang-undang Islam secara amnya dan banyak yang cenderung kepada pandangan mazhab Hanbali secara khususnya, berkenaan tanggungjawab saudara-mara untuk menyediakan nafkah kepada saudara-mara yang lain. Bagi negara Malaysia, sekalipun tidak ada peruntukan khusus yang mengawal selia urusan nafkah terhadap saudara-mara di bawah undang-undang Malaysia, peruntukan umum mengenai kuasa mahkamah untuk memerintahkan pembayaran kepada saudara-mara mencerminkan bahawa, undang-undang di Malaysia cuba untuk melindungi kepentingan dan kebajikan ahli keluarga dan saudara-mara. Walau bagaimanapun, untuk melindungi kepentingan dan kebajikan semua saudara-mara dengan lebih baik, dicadangkan satu peruntukan terperinci berkenaan nafkah terhadap saudara-mara termasuk nafkah yang berdasarkan bahagian dalam pewarisan. Tambahan pula, dengan cara ini juga akan memberikan gambaran yang jelas berkenaan hak dan tanggungjawab individu terhadap ahli keluarga yang lain. 


\section{RUJUKAN}

Akta Undang-undang (Wilayah-Wilayah Persekutuan) 1984.

'Ala-addin Abu al-Hasan Ali ibn Sulayman al-Mardawi al-Damsyiki al-Mazhab Hanbali. (t.t.). Al-Insaf fi Ma'rifat al-Rajih min al-Khilaf (Edisi Kedua). Beirut: Dar Ihya al-Turath.

Abu Dawud, Sulayman ibn al-Ash'ath ibn Ishaq ibn Bashir ibn Shaddad ibn 'Amru al-Azdi al-Sijistani. (t.t.). Sunan Abi Dawud. Beirut: al-Maktabah al'Asriyyah.

Ahmad ibn Ali Abu Bakr al-Razi al-Jassas al-Mazhab Hanafi. (1405H). Ahkam al-Quran. Beirut: Dar Ihya al-Turath.

Ahmad Muhammad Ismail Barraj. (2013). Al-Dhaman al-Ijtima'I fi al-Fiqh alIslami, Iskandariyyah; Dar al-Jami'ah al-Jadidah.

al-Ba'albaki. (1994.) R. Al-Mawrid, Modern Arabic English Dictionary (Edisi Keenam). Dar al-'Ilmi li al-Malayin.

al-Bahuti, Mansur ibn Yunus ibn Solahuddin ibn Hassan ibn Idris al-Mazhab Hanbali. (t.t.). Kashshaf al-Qana' 'an Matn al-Iqna'. Beirut: Dar al-Kutub al-'Ilmiyyah.

al-Hattab al-Ru'aini, Shamsuddin Abu Abdullah Muhammad ibn Muhammad ibn Abdurrahman al-Tarablusi. (1992). Mawahib al-Jalil fi Sharh Mukhtasar Khalil (Edisi Ketiga) Beirut: Dar al-Fikr.

al-Kasani, 'Ala-addin Abu Bakr ibn Mas'ud ibn Ahmad al- Kasani al-Mazhab Hanafi. (1986). Badai' al-Sanai' fi Tartib al-Sharai' (Edisi Kedua). Beirut: Dar al-Kutub al-'Ilmiyyah.

al-Khatib al-Sharbini, Shamsuddin Muhammad ibn Ahmad. (1994). Mughni al-Muhtaj ila Ma'rifah Ma'ani Alfaz al-Minhaj. Beirut: Dar al-Kutub al'Ilmiyyah.

al-Nawawi, Abu Zakariyya Mahyuddin Yahya ibn Sharaf. (1991). Rawdah alTalibin wa 'Umdah al-Muftin (Edisi Ketiga). Beirut: al-Maktab al-Islami.

al-Nasa-ie, Abu Abdurrahman Ahmad ibn Shu'aib ibn Ali al-Khurasani. (1986). Al-Sunan al-Sughra li an-Nasa-ie. (Edisi Kedua). Halab: Maktab alMatbu'aat al-Islamiyyah.

al-Shirazi, Abu Ishaq Ibrahim ibn Ali ibn Yusuf. (t.t.). Al-Muhadhdhab fi al-Fiqh al-Imam Al-Shafi'e. Beirut: Dar al-Kutub al-'Ilmiyyah.

Enakmen Undang-undang Keluarga Islam (Negeri Sembilan) 2003.

Fakhruddin al-Zayla'ie, 'Uthman ibn 'Ali ibn Muhjan al-Bari'ie al-Mazhab Hanafi. (1312H). Tabyin al-Haqaiq Sharh Kanz al-Daqaiq. Kaherah: Maktabah al-Kubra al-Amiriyyah.

Ibn al-Humam, Kamaluddin Muhammad ibn 'Abdul-Wahid al-Siwasi. (t.t.). Fath al-Qadir. Beirut: Dar al-Fikr.

Ibn Nujaym al-Misri, Zainuddin ibn Ibrahim ibn Muhammad. (t.t.). Al-Bahr alRaiq Sharh Kanz al-Daqaiq (Edisi Kedua). n.p.: Dar al-Kitab al-Islami. 
Ibn Qudamah al-Maqdisi, Abu Muhammad Muwafiquddin Abdullah ibn Ahmad ibn Muhammad al-Mazhab Hanbali. (1994). Al-Kafi fi Fiqh al-Imam Ahmad. Beirut: Dar al-Kutub al-'Ilmiyyah.

Ibn Qudamah al-Maqdisi, Abu Muhammad Muwafiquddin Abdullah ibn Ahmad ibn Muhammad al-Mazhab Hanbali. (t.t.). Al-Mughni. Kaherah: Maktabah Kaherah.

Kassim bin Othman \& Fatimah binti Salleh lwn Raja Suzana binti Raja Kasim \& Zul Azli bin Hashim, (2010) $30 \mathrm{JH}(2), 299$.

Muhammad ibn Ahmad ibn 'Arafah al-Dusuqi. (t.t.). Hashiah al-Dusuqi 'ala alSharh al-Kabir. Beirut: Dar al-Fikr.

Muhammad 'Aqalah (2010), Nizam al-Usrah fi al-Islam. Juzuk 3, Cetakan Keempat. Amman: Maktabah al-Risalah al-Hadithah.

Muhammad Mustafa Shalabi. (1977). Ahkam al-Usrah fi al-Islam. Beirut: Dar al-Nahdah al-'Arabiyyah.

Mustafa al-Khin, Mustafa al-Bugha, \& Ali al-Shurbaji. (1992). Al-Fiqh alManhaji 'ala Mazhab al-Imam al-Shafi'e (Edisi Keempat). Damsyik: Dar al-Qalam.

Nasiruddin al-Khattab. (2007). English Translation of Sunan An-Nasa-ie. Riyadh: Darussalam.

Qanun Ittihadi (UAE) 2005.

Rashad Hasan Khalil. (1987). Nafaqat al-Aqarib fi al-Fiqh al-Islami. Kaherah: Dar al-Manar.

Undang-Undang Keluarga Iraq 1959.

Undang-Undang Keluarga Qatar 2006.

Wizarah al-Awqaf wa al-Shu'un al-Islamiyyah. (2002). Al-Mawsu'ah alFiqhiyyah. Kuwait: Wizarah al-Awqaf wa al-Shu'un al-Islamiyyah.

Zakariyya ibn Muhammad ibn Zakariyya al-Ansari. (t.t.). Asna al-Matalib $f i$ Sharh Rawd al-Talib. N.p.: Da al-Kitab Islami.

Zaki al-Din Sha'aban. (1993). Al-Ahkam al-Shar'iyyah li al-Ahwal al-Shakhsiyyah ( $6^{\text {th }}$ Edition). Banghazi. Jami'ah Qaryunis.

Diperoleh (received): 30 September 2019

Diterima (accepted): 29 Jun 2020 